\title{
Moral Autonomy and Habituation Method: A Study Based on Islamic Teachings
}

\author{
*JAVAD FAKHKHAR TOOSI \\ ASYRAF ISYRAQI BIN JAMIL \\ MOHD YAKUB@ZULKIFLI BIN MOHD YUSOFF \\ Islamic Education Programme, Academy of Islamic Studies, University of Malaya, \\ Kuala Lumpur, Malaysia \\ *Corresponding author: j.fakhar.t@gmail.com
}

Published online: 15 August 2019

To cite this article: Toosi, J.F., Jamil, A.I. and Mohd Yusoff, M.Y.Z. 2019. Moral autonomy and habituation method: A study based on Islamic teachings. KEMANUSIAAN the Asian Journal of Humanities 26(Supp.1): 47-61. https://doi.org/10.21315/kajh2019.26.s1.3

To link to this article: https://doi.org/10.21315/kajh2019.26.s1.3

\begin{abstract}
The current paper seeks to illustrate the conflict between habituation and moral autonomy and explain the Islamic view in this regard. The methodology of this research is qualitative and Islamic classical sources have been used to further elucidate Islam's stance, as we have referred to some articles and resources to understand the concept of habituation method and its contradictions with moral autonomy. The achievement of the paper is realising the contradiction between the habituation method and moral autonomy and habituation's incompatibility with the rational growth and development of the youth which is the goal of Islamic education. Therefore, this method cannot be accepted in Islamic moral education. On the other hand, there are some narratives in the Islamic sources that apparently have recommended this method, so another important achievement of the article is the proper interpretation of these narratives, presented for the first time. According to this interpretation, these narratives do not recommend the habituation method, but rather the continuity and maintenance of the action. Therefore, there is no disapproval in Islamic sources in this regard, and these sources reject the use of this method in moral education. The paper concludes by saying that the habituation method is not an Islamic method of education, and Islamic narrations have not recommended it. This paper comes with a suggestion that education scholars and policy makers need to extract other methods from the Islamic sources and devise them according to scientific findings instead of using this method.
\end{abstract}

Keywords and phrases: moral autonomy, habituation method, Islamic teaching, Islamic perspective, educational methods 


\section{Introduction}

While moral education is one of the sub-topics of education and should be introduced and defined under this title, it is also related to a particular area of education, such as social education, political education, sex education, etc. (Hayden 2017). For this reason, moral education is known to indicate transferring of the moral values to a recipient (McCamant 2018); or as it is being defined: "Moral education is the cultivation of virtues in human beings" (Han et al. 2018).

Following these definitions, it is evident that there are two main approaches to achieve the goal of moral education. First, the one that considers education as the formation of moral habits in a person. One which claims that internalising ethical principles so that they become personal habits and that the agents act upon them immediately in any situation without prior thinking. Among the proponents of this approach are Auguste Comte (Sanduk 2012, 108), Lucien Lévy-Bruhl (Marková and Jesuino 2018) and Émile Durkheim (Prus 2011). They believe that moral education prepares learners to behave easily and automatically at any given situation requiring the moral act. The second approach is to bring the person to an insight and moral understanding. Accordingly, moral education is defined as "teaching and instilling the ethical concepts and values to learners" (Mejía and Montoya 2017). They see moral education as not one on practising ethical behaviours and turning them into habits, but rather creating a person's moral recognition and intuition in a way that they do not need to induce or inculcate external moral concepts and values. Hence, they are able to recognise the good and the bad at any given circumstance (Mejía and Montoya 2017).

The educational methods are used by educational policy makers and administrators to transfer values and education's content to learners and guide them to the objectives (Bredesen et al. 2016). These methods have an instrumental role in conveying the values and content. The determination and selection of methods is based on the role they play in transferring and the delivery process. Therefore, any method playing a more vigorous role in this process will be considered (Al-Attas 1979, 176).

One of the methods highlighted by scholars in moral education is the use of habituation. In this method, people try to get used to moral behaviour and manner. They behave normally and spontaneously, without the need for deep thinking or decision. In order to achieve a consistent moral state malakah (ملكة), one needs to use the normalisation and habituation method. Habit is defined as "an automated, orderly and coordinated relation between all the spiritual activities of the individual" and "repeating an action in close proximity" is another definition (Singh et al. 
2015). Scholars also say that it is "encouraging someone to accept getting used to a habit, in such a way that it regulates their behaviour in the long run" (Kerr 2011). One can also define habituation as "learning the excellences of character through engaging in virtuous behaviour and avoiding non-virtuous behaviours" (Kerr 2011, 644).

The habituation method conflicts with the moral autonomy that symbolises the modern education (Rynn 2012). While in Islamic sources, there are some evidences that confirm the use of this method. Hence, many scholars have criticised the Islamic education from this perspective (see Halstead 2007). In the present study, we try to interpret the evidences in a different manner and conclude that Islam does not recommend using this method and does not accept it as a training strategy. Hence, there is no ground for criticism of Islamic education.

The importance of the article is clarified through the moral autonomy seen as a symbol of modern education (see Alamri 2016). If there were any incompatible method with moral autonomy recommended in Islam, establishing a dialogue between Islamic education and modern education would be difficult. Therefore, the present article addresses one of the most significant problems in the way of this interaction and dialogue. Firstly, by showing that the method of habituation is not an Islamic method, and secondly, by providing a unique interpretation of some of the traditions and evidence in the Islamic sources, which apparently approve the habituation method. The study also aims to find out which of these narratives do not relate to the habituation method.

\section{Literature Review}

Researchers in the field of habituation method from the Islamic perspective can be classified into two categories. First, researchers who solely write to criticise the Islamic educational system which uses this method. Among these critics are Aidaros, Shamsudin and Idris (2013), Elegido (2000), Gillespie (2016) and Moore (2012). Second, researchers who write in defence of the Islamic educational system. In these studies, habituation is approved and they have divided this method into two categories: acceptable and unacceptable. Kerr (2011), Kristjánsson (2016), Räihä et al. (2012) and Turgut (2016) are among those who have divided the method of habituation into the two types of mechanical and cognitive manners. They have sought to show that Islam has recommended the habituation method. Morteza Mutahhari (2007) is another scholar who claims that the method of passive habituation is rejected by Islamic teachings, and the active habituation method, is therefore approved. 
We will further discuss and prove that all these divisions are due to misunderstandings of the nature of the habit and habituation. An act, either consciously or mechanically, when is adapted in other words habituated, is no longer based on active thought or decision-making, hence will be in conflict with the moral independence which is the goal of education. In the arguing for an active and passive habituation, the same statement can also be put forward.

The difference between the present research and other works so far, and the importance of the current study is that by examining the Islamic evidence, we are able to prove that habituation cannot be used as an educational method in general, and Islam has not accepted it. Hence, one cannot criticise Islam based on this method.

\section{Research Methodology}

The research method in this paper will be qualitative. The reason for using this method is that, in order to assess Islamic stance regarding the use of the habituation method, there is a need for theoretical and fundamental discourse. Therefore, we need a qualitative research, which is the proper method for creating theories (Lane 2011). Using the qualitative method, instead of testing the existing theories, it will enable us to obtain new original theory in this field (Atkinson 2017).

\section{Findings and Discussion}

According to Aristotle, the habit, not only simplifies action and eliminates the suffering of effort, but also intensifies it (Singh et al. 2015). In his view, repetition produces habits and habits produce inclination, and desire, in turn, raises action, the result of this, is a certain type of knowledge (Kerr 2011). Aristotle's phrase shows his view in this regard, saying in the essay, Nicomachean Ethics:

Virtue cannot be found except through habit. Our nature has given us several talents. We convert these talents to a steady state through the use of them and their continued maintenance. Because no one can do good unless he does is constantly. The most significance belongs to the habit; so one needs to get used to good behaviour from one's childhood. Because virtue is virtuous divided into rational and ethical, and rational virtue is acquired through learning and therefore requires experience and time. But moral virtue comes from the way of habit and nature. (Aristotle 1921, 1: 27). 
Muslim thinkers influenced by the Aristotelian tradition, chose habituation as the most important form of education (Attaran 2015, 44). The method was raised in the Islamic ethics and education, as a way for the creation of the stable state of malakah (ملكة). What the Muslim scholars have meant by the state malakah, is a constant and permanent mental and spiritual state of the human soul (see Suhrawardi 1997). Many Islamic scholars have mentioned worship such as prayer or șalāt (صلاة), fasting or șawm (صوم), remembrance of God or dhikr (ذكر) and so on, as evidence for the acceptance of habit as one of the educational methods in Islam. They believe that habit includes accompaniment, perseverance and protection, and all of them are essential; because continuity without constructive protection is not useful, and the protection of your constancy is not at all constructive, because although it is very transcendental, it will disappear by time (Al-Razi 1999).

The problem with utilising the method of habituation in the field of moral education lies in the inverse relationship between this method and reasoning and thinking. According to the scholars, the use of this method leads to the diminishing of the power of reason (Kristjánsson 2014, 34).

At the same time, other researchers believe in this method as a useful way in moral education. Although in the current paper we are seeking to understand the position of Islam on this method, first let's examines what these scholars have done in defending the habituation method. Afterwards we provide the grounds for the next step to examine the Islamic evidence.

\section{The critical discussion with the supporters of the habituation method}

The scholars who have sought to defend the habituation method could not overlook the many weaknesses of this method, which can be summarised in undermining rationality and individual independence. For this reason, they have tried to divide the habits into good and bad. In the next step, they have attempted to associate the disadvantages only with the bad habits, and conclude that, good habits are free of such flaws.

Some of them have divided habits into two categories: mechanical and cognitive manner (see Burnyeat 1999; Lännström 2006; Sherman 1999). These scholars only insist on the point that, practice and repetition must be carried out consciously. According to Nancy Sherman (as quoted in Kerr 2011, 648): "The exterior moment of action cannot be isolated from the "interior cognitive and affective moments which characterize even the beginner's ethical behaviour". 
We believe that the division of habits into mechanical and cognitive cannot solve the problem of the incompatibility of the habituation method with moral autonomy. The two types of habits are different only in the sense of the exercise and practice. They share a common goal which is to elevate a person to a point that they perform good deeds on the basis of habit. What confirms our point here is the views of many scholars who have considered the lack of decision making and prior thought as the main indicator of habit (Ersche et al. 2017). We know that the critique of the habituation method in both mechanical and cognitive is exactly at this final stage (thinking-decision). The critique is that, this method disregards the position of human reason, and what the person performs is not based on reasoning and following the laws of wisdom. In fact, in this method, the first and most important element of the moral autonomy is abandoned, and the person who performs deeds in a normal way and not based on previous thinking.

Some other defender scholars divide habits into two types of active and passive habits (Mutahhari 2007, 57). In their opinion the active habit is that, humans are not influenced by an external agent, but rather, do things in the form of repetition and continuity. Mutahhari says, "Writing is a habit, not a knowledge. Our ability for writing is a result of habit. By practice we get used to writing gradually" $(2007,57)$. He believes that Islamic education, in the sense of habituation and creation of steady state (الملكات النفسانية) is related to this kind of habit (Mutahhari 2007). He further stated his view:

The steady state (الملكة) is an example of active habits. For example, the courage is a steady state that is formed by repeating positions and situations. When someone repeatedly confronts a dangerous situation and shows his stability, he will reach the steady state of courage. (Mutahhari 2007, 58)

According to Mutahhari, these types of habits have no problems and their usage as an educational method is not wrong. Because in this kind of habits, one does not get accustomed to a particular act, but he only strengthens the resistance towards the phenomenon, that is, until he is not used to it, his will is weak against this phenomenon, and after he becomes accustomed, his will becomes stronger (Mutahhari 2007).

The inaccuracy of Mutahhari's view is clear and needs to be explained. Firstly, the nature of active habits is not different from the nature of passive habits. In either case, the human nature becomes adapted to a particular task or a phenomenon, and it is not done based on any form of decision making or thought. What comes forward regarding active habits as a reinforcement of the will is the same in the 
passive habits. Basically, those who defend the habituation as an educational method emphasise the impact of this method on strengthening the will as the benefit of this method, so it does not devote to the active habits (see for example, Al-Zahrani 2015; Coles 2017; Trenberth 2005).

Secondly, Mutahhari puts these habits against knowledge and concludes that, these are like art and techniques $(2007,59)$. This is also incorrect; art and techniques are types of practical skills and essentially different from morality and moral education. As in the example of writing (that he mentioned before), we learn how to write different words and lines, this is a form of learning and education. The method of learning in the theoretical science is indeed different from practical sciences. In order to learn in this type of knowledge, the organs must also accompany the mind. But this does not make the nature of these skills identical to the nature of ethical habits. Attention to practical knowledge along with theoretical knowledge is the focus of most of the scientists who have studied this field (see for example, Katajavuori, Lindblom-Ylänne and Hirvonen 2006; Tynjälä et al. 2016). Therefore, ethical issues and moral education are fundamentally different from those of practical skills, and Mutahhari made a mistake by confusing the two. In other words, our subject is moral education which has nothing to do with practical skills such as writing and so on.

Thirdly, it seems that Mutahhari does not have a proper perception and interpretation of the concept of habit. He stated that:

Imagine someone who's got accustomed to getting up early. It's hard for one to get up early before internalizing this habit. So he tries to make it easy. For a while, he practices, then he becomes accustomed to waking up early in the morning, and it's nothing but getting it easy. In other words, it was previously captured by nature. By virtue of this habit, a force that is found equal to the force of nature, and it gets free between the two forces, then it deliberates with its wisdom and decides to sleep or wake up. This cannot be harmful. (Mutahhari 2007, 58)

In the example that Mutahhari has put forward, the person has not yet been habituated. If he is in the habit, he will be woken up naturally early in the morning. We cannot say that he is in the pre-habit stage which encourages him to sleep equally as the force of his habit that wakes him up early. The truth is, when a person needs to use the power of reason and thinking to wake up or sleep, means that he has not yet reached the habituation stage. Basically, the habit makes one do things naturally without thinking or making decisions. 
On the other hand, according to Mutahhari, the habit is considered as secondary to the nature of man, and one should not weaken his nature to strengthen the power of reason and his will. He says: "This is like eradicating the human instincts to strengthen the faith and ethics, as some do by sterilizing themselves to prevent sexual provocations" (Mutahhari 2007, 58). What is clear in Mutahhari's words is a false understanding of the habit (as we have mentioned before). How can we get used to doing something, and at the same time decide on the basis of free will and thought? He himself acknowledges that the habit is considered as secondary to the nature of man, so the act done based on habit, as well as other natural acts of human being, is exported.

Fourth, the second kind of habits that Mutahhari has raised is passive habits. According to him, passive habits are "habits that human beings acquire under the influence of an external agent. Like smoking, that is, man always wants to smoke. The passive habits usually make man accustomed to things and captivate them" (Mutahhari 2007, 58).

While we know that, our critique of the habituation method does not relate to the source of the habit, but rather the nature and the function of the habit. It does not matter whether the habit is shaped by external factors or the inner influence (practice and repetition). The significance of it is leading the person to a stage that it is done in an impulsive way, without the need for thinking or decision making, and this contradicts moral autonomy.

\section{Habituation method in the Islamic sources}

We are confronted with two sets of Islamic evidence. Many of them have prohibited the use of this method. But in some, the use of this method is recommended. We must study the two categories and resolve their apparent contradictions and conflicts in order to obtain the position of Islam in this regard.

\section{Traditions that apparently accept the use of habituation}

Many narrations have been quoted from Ali Ibn Abi Talib that emphasise the use of habituation. For example, saying: "تخير لنفسك من كل خير أحسنه فإن الخير عادة" (Ibn Salamah 1983, 68) means "give of the good things the best of them, because good will come from habit". Another saying is "

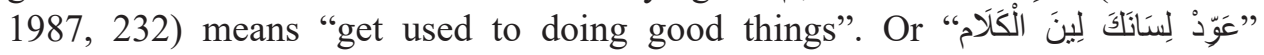
(Al-Amidi 1987, 435) which means "get used to your tongue to say good things". 
Another saying "كَفَى بِفعْلِ الَْنِْر حُسْنُ عَادَة" (Al-Amidi 1987, 105) would bring the meaning of the "habit of doing good is enough to make a person good" and

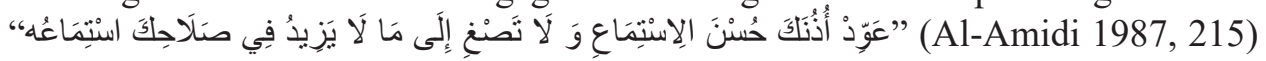
means "use your ears to hear good words, and avoid listening to bad words".

We do not want to discuss these narrations in terms of their sources. None of these narrations have been quoted from the authentic sources of Ahl al-Sunnah (اهل السنة و الجماعة). Assuming that we can accept these narratives - that are quoted in non-Sunni sources - we will go through them. When confronting these narrations, it should be considered that, by these narratives what is intended is the continuity of action and impulsively doing it. Needless to say, that the purpose of the habit is automatically performing, without thinking or decision making. So, what has been said in these narratives, is the continuation of its practice and its continuous pursuit, which does not necessarily mean mechanical and impulsive behaviour. Someone may continuously behave throughout his lifetime, but always on the basis of previous thinking, always taking it on the basis of the task, in which, he or she feels, and doing it with the previous decision. This is a desirable Islamic moral education, not blind, automatic behaviour based on habituations. This is an important point in understanding the narrations that seem to support the habit. All these narratives emphasise the continuity and duration of action, and there is no reason to recommend habituation in such a way as to act without thought and decision.

The narratives that we mention in the following, reinforce this interpretation. For example, Abu Hurairah has quoted from the Prophet (Ibn Hanbal 1991, 2:350):

$$
\text { كلفو ا من العمل ما تطيقون فان خير العمل ادومه }
$$

which means "Make yourself, do your tasks, because the best thing is that have more continuity". Bukhari has quoted from Aisha from the Prophet (Bukhari 1981, 1:16):

$$
\text { كان احب الدين اليه ما داوم عليه صاحبه }
$$

which means "God's most beloved is that its doer does it more and more".

This is an important point for understanding the narrations that seem to support the habit. All these narratives emphasise the continuity and duration of the action, and there is no reason to recommend habituation in such a way as to act impulsively 
or without making a decision. In Islamic sources, there are also statements that confirm this interpretation. For example, in a narrative quoted by Bukhari (1981, 2:44) the Prophet says:

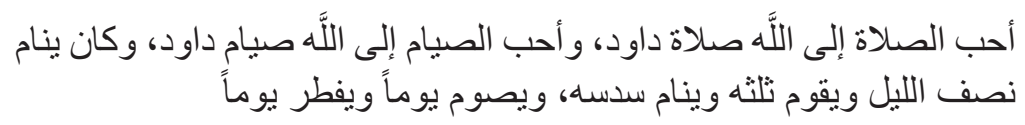

Which means:

The most cherished prayer in the sight of God was David's prayer, and the most cherished fasting in the sight of the Lord was also the fasting that David did. He sometimes slept half of the night and left one third of it worshiping, and sometimes he slept one sixth of the night, and David would fast for a day and not fast another day.

Based on this tradition, David did not allow worship to become his daily habit and to lose its effect. It is interesting that Al-Ghazali, who is an attentive follower of the habituation method in moral education, describes this tradition the same way as we did. According to him the reason for the popularity of David's prayer is that, it was not based on his habit. Al-Ghazali as al-Munawi has quoted says:

The reason for the popularity of David's worship is that, to a person who has fasted for a long time, usually fasting becomes his daily habit, then he does not feel the effects of fasting in his heart. Fasting will make a difference when one feels that he is not yet used to it, and it will not have any effect when he is practicing fasting. Like doctors recommend that one should not be used to taking medicine, and they say that it is not beneficial for someone who is accustomed to medicine. Because his temperament is accustomed to the medicine and it no longer influences.

(Al-Munawi 1995, 1:222)

Upon quoting this statement, al-Munawi accepted it as the best interpretation about this narrative. The interesting point is presenting this interpretation by those who are themselves proponents of the habituation method in moral education. It is clear that these scholars have no choice but to interpret the purpose of the prophet in a way that is against the habituation.

The result of the investigations is that, it cannot be relied on narrations to claim that Islam has recommended habituation as a method. Because, these traditions can be interpreted in such a way as to be consistent with the continuity and frequency of the act, rather than becoming accustomed to it. So, the way to prove this method is not available. 


\section{Traditions that refute the use of habituation}

We have seen that, narratives that seem to recommend the method of habituation, are all justifiable and interpretable, and it can be said that, the narratives have considered repetition and continuity of action rather than it becoming a habit. The result of the study is that, the advocates of the habituation method cannot argue with these narratives in order to prove the acceptance of the habituation method in Islamic teachings.

Contrary to the aforementioned narrations, there are some traditions that advise against the use of the habituation method. These traditions are abundant, and we only quote some examples here. For example, as quoted from Ali Ibn Abi Talib: "العادة عدو متملك" (Al-Leythi 1997, 248) which means "habit is an enemy that dominates the human being (and takes his freedom)". Another saying, "غالبوا انفسكم على ترك العادات" (Al-Leythi 1997, 348) which means "get rid of your habits, then gain your control and get your freedom" or another quote from the Prophet Muhammad (Al-Hakim Nishapuri 2002, 3:231):

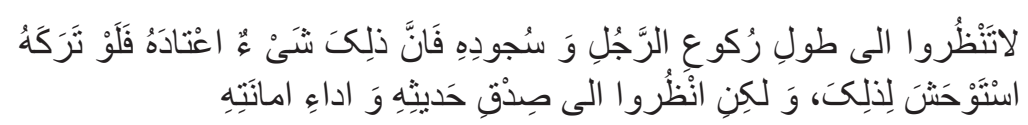

with the meaning "Do not pay attention to the prayers of a person, because he often does this worship in accordance with his habitually. The habit that denouncing is irritating, so pay attention to the truth and honesty". This hadith clearly states that even the worship by the habit is worthless.

With these narratives, we can properly understand the interpretation we have made about the earlier category of traditions (which were apparently supportive for habituation), and it turns out that, the habituation raised in those traditions is intended to be the continuity and the frequency of the action.

So far we learn that the use of the habituation method must be rejected by moral education according to the Islamic evidences. Request and insist of mentor for the continuation and repetition of the desired behaviour of the student or child and adolescent is among the most prominent examples of the habituation method. This repetition, which is used extensively in the Islamic educational area and especially religious schools, students are attempting to replicate specific acts at specific times. The purpose of this repetition is the formation of habits in children and students, that we know its incompatibility with moral autonomy and Islamic teachings. The repetitious ritual for the purpose of habituation does not lead to the formation of ethical behaviour based on reasoning and intuition, and eventually leads to an impersonal ritual of continually repeated acts. 


\section{Conclusion}

In the present paper, we first examined the concepts of habituation, moral independence (autonomy) and moral education. We introduced ethical independence (autonomy) as a goal of education. Next, we identified that the use of the habituation method in moral education has been raised in many Islamic sources, while this method contrasts with the moral independence (autonomy).

The scholars who defended this method, have not been able to ignore the weaknesses of this method, including the conflict with independence and individual thinking. Therefore, they have often accepted the division of habits into good and bad. However, we have shown that habit (in both cases) is an action that is not based on decision-making and thinking, hence there is a degree of conflict with independence and rationality.

On the other hand, many have claimed that, Islamic narrations have recommended the use of this method. We reflected on the traditions to solve this problem, which encompasses of two narrative categories. The first one apparently recommends using this method; and the second part, which is more explicit and in terms of number are much more, has rejected this method. In reviewing the first method, we studied the text without considering the unreliability of the source of these traditions, since they have not been mentioned in the Sunni sources. It was because we showed that even by accepting these narratives, it cannot be proven that Islam uses the habituation method. What was said in the review of these traditions was that, the aforementioned narrations do not have to do with habituation but necessitates the continuity and frequency of the act. Of course, continuity does not mean habituating; because it is possible that a person does something continuously but thinks about it every time and decides on the benefits of working. The second group of narratives, as stated above, have explicitly rejected the habituation method and devalued what has been done for habits.

The conclusion leads us to specific suggestions, which are: (1) as a specific education policy, the use of habituation methods in homes and schools for the moral training of the youth and adolescents must be abolished; (2) to identify the common examples of habituation method, teachers and parents must be advised to set aside these examples; and (3) instead of these examples, other cases that enhance the rationality and thoughtfulness of the youth and adolescents must be introduced and recommended to parents and teachers. 


\section{References}

Aidaros, H., Shamsudin, F. and Idris, K. 2013. Ethics and ethical theories from an Islamic perspective. International Journal of Islamic Thought 4: 1-13. https://doi. org/10.24035/ijit.04.2013.001

Al-Amidi, A'.1987. تصنيف غرر الحكم و درر الكلم/CGhurar al-Hikam wa Durar al-Kalim]. Iran: Islamic Propagation Office. https://doi.org/10.1163/9789004223196.srg-76

Al-Attas, S.M.N. 1979. Aims and objectives of Islamic education. London: Hodder \& Stoughton.

Al-Hakim Nishapuri, M. 2002. المستدرك على الصحيحين [Al-Mustadrak alaa al-Sahihain]. Lebanon: Dar al-Kutub al-E'lmiyyah.

Al-Leythi, A'. 1997. عيون الحكم و المواعظ [U'yoon al Helam wa al Mawae'z]. Iran: Dar alHadith.

Al-Munawi, M. 1995. فيض القديرشرح جامع الصغى [Fayd al-Qadir Sharh al-Jami`al-Saghir]. Lebanon: Dar al-Kutub al-E'lmiyyah.

Al-Razi, F. 1999. مفاتيح الغيب [Mafatih Al Qeiyb]. Lebanon: Dar Ihya al-Turath al-A'rabi.

Al-Zahrani, A.M. 2015. From passive to active: The impact of the flipped classroom through social learning platforms on higher education students' creative thinking. British Journal of Educational Technology 46(6): 1133-1148. https://doi.org/10.1111/ bjet. 12353

Alamri, A. 2016. How can a focus on the ethical notions of dignity and respect for autonomy help to improve healthcare for elderly people in Islamic countries? (Order No. 10110350). Available from ProQuest Dissertations and Theses Global (1797426820). http://ezproxy.um.edu.my:2048/login?url=https://search.proquest. com/docview/1797426820?accountid=28930 (accessed 10 September 2018).

Aristotle. 1921. Nicomachean ethics. Cairo: Dar S'ader.

Atkinson, J. 2017. Qualitative methods. In Journey into social activism: Qualitative approaches, pp. 65-98. New York: Fordham University. http://www.jstor.org. ezproxy.um.edu.my/stable/j.ctt1hfr0rk.6 (accessed 12 September 2018).

Attaran, M. 2015. Moral education, habituation, and divine assistance in view of Ghazali. Journal of Research on Christian Education 24(1): 43-51. https://doi.org/10.1080/ 10656219.2015.1008083

Bredesen, I.M., Bjøro, K., Gunningberg, L. and Hofoss, D. 2016. Effect of e-learning program on risk assessment and pressure ulcer classification: A randomized study. Nurse Education Today 40: 191-197. https://doi.org/10.1016/j.nedt.2016.03.008

Bukhari, M. 1981. صحيح البخار [Sahih al-Bukhari]. Lebanon: Dar al-Fikr.

Burnyeat, M.F. 1999. Culture and society in Plato's Republic. Tanner Lectures on Human Values 20: 215-324.

Coles, A. 2017. Habits and binds of mathematics education in the anthropocene. Philosophy of Mathematics Education Journal 32: 1-15.

Elegido, J.M. 2000. Fundamental of business ethics: A developing countries perspective. Lagos: Spectrum Books Ltd. 
Ersche, K.D., Lim, T.-V., Ward, L.H.E., Robbins, T.W. and Stochl, J. 2017. Creature of habit: A self-report measure of habitual routines and automatic tendencies in everyday life. Personality \& Individual Differences 116: 73-85. https://doi. org/10.1016/j.paid.2017.04.024

Gillespie, R. 2016. Religion and the post secular public sphere. Quarterly Journal of Speech 102(2): 194-207. https://doi.org/10.1080/00335630.2016.1155747

Halstead, J.M. 2007. Islamic values: A distinctive framework for moral education? Journal of Moral Education 36(3): 283-296. https://doi.org/10.1080/03057240701643056

Han, H., Park, S.C., Kim, J., Jeong, C., Kunii, Y. and Kim, S. 2018. A quantitative analysis of moral exemplars presented in moral education textbooks in Korea and Japan. Asia Pacific Journal of Education 38(1): 62-77. https://doi.org/10.1080/02188791 .2018 .1423950

Hayden, M. 2017. Education in morality through natality: No more morals. Teaching Ethics 17(1): 9-22. https://doi.org/10.5840/tej20176645

Ibn Hanbal, A. 1991. Al-Musanad. Lebanon: Dar Ehya al-Torath al-A'rabi.

Ibn Salamah, M. 1983. دستور معالم الحكم و مأثورمكارم الثيم [Dastu'r Ma'alem al Hukm wa Ma'thu'r Makerm al shiym]. Iran: Maktabatul Mufid.

Katajavuori, N., Lindblom-Ylänne, S. and Hirvonen, J. 2006. The significance of practical training in linking theoretical studies with practice. Higher Education 51(3): 439464. https://doi.org/10.1007/s10734-004-6391-8

Kerr, D. 2003. Conceptualizing autonomy for education. Canada: The University of British Columbia.

Kerr, J. 2011. Habituation: A method for cultivating starting points in the ethical life. Journal of Philosophy of Education 45(4): 643-655. https://doi.org/10.1111/j.14679752.2011.00826.x

Kristjánsson, K. 2014. There is something about Aristotle: The pros and cons of Aristotelianism in contemporary moral education. Journal of Philosophy of Education 48(1): 48-68. https://doi.org/10.1111/1467-9752.12047

2016. Aristotelian character education: A response to commentators. Journal of Moral Education 45(4): 527-534. https://doi.org/10.1080/03057240.2016.1244050

Lane, J. 2011. A descriptive analysis of qualitative research published in two eminent music education research journals. Bulletin of the Council for Research in Music Education 188: 65-76.

Lännström, A. 2006. Loving the fine: Virtue and happiness in Aristotle's ethics. Notre Dame, IN: University of Notre Dame Press. https://doi.org/10.1111/j.14682265.2012.00748_13.x

Marková, I. and Jesuino, J.C. 2018. Social psychology as a developmental discipline in the dynamics of practical life: Gustav Jahoda's pioneering studies on children's social thinking. Culture \& Psychology 24(3): 343-357. https://doi. org/10.1177/1354067X18779035

McCamant, J. 2018. Getting to scale with moral education: The demands of reproducibility and the case of the Chicago Manual Training School, 1884-1904. Teachers College Record 120(7): 1-38. 
Mejía, A. and Montoya, S.E. 2017. On the meeting of the moral and the aesthetic in literary education. Journal of Philosophy of Education 51(2): 370-386. https://doi. org/10.1111/1467-9752.12237

Moore, J.G. 2012. Kant, religion, and politics. Choice: Current Reviews for Academic Libraries 49(10): 1886.

Mutahhari, M. 2007. The philosophy of education. Iran: Sadra Publisher.

Prus, R. 2011. Examining community life 'in the making': Emile Durkheim's moral education. American Sociologist 42(1): 56-111. https://doi.org/10.1007/s12108010-9119-5

Räihä, T., Tossavainen, K., Turunen, H., Enkenberg, J. and Kiviniemi, V. 2012. Effects of nutrition health intervention on pupils' nutrition knowledge and eating habits. Scandinavian Journal of Educational Research 56(3): 277-294. https://doi.org/10. 1080/00313831.2011.581688

Rynn, M.Y. 2012. On tolerance: A defence of moral independence. Choice: Current Reviews for Academic Libraries 49(9): 1745.

Sanduk, M. 2012. Is the technology a new way of thinking? Journal of Technology Studies 38(2): 105-114.

Sherman, N. 1999. The fabric of character. In Aristotle's ethics: Critical essays, ed. N. Sherman. New York: Rowman and Littlefield.

Singh, L., Fu, C.L., Rahman, A.A., Hameed, W.B., Sanmugam, S., Agarwal, P., Jiang, B., Chong Y.S., Meaney, M.J and Rifkin-Graboi, A. 2015. Back to basics: A bilingual advantage in infant visual habituation. Child Development 86(1): 294302. https://doi.org/10.1111/cdev.12271

Suhrawardi, Y. 1997. Mjmua'h Al mus'annfat Al sheikh Al Ishraq. Iran: Institute for Cultural Studies and Research.

Trenberth, L. 2005. The role, nature and purpose of leisure and its contribution to individual development and well-being. British Journal of Guidance \& Counselling 33(1): 1-6. https://doi.org/10.1080/03069880412331335849

Turgut, H. 2016. Pre-service science teachers' perceptions about relationship between religion and science in the context of their worldviews. International Online Journal of Educational Sciences 8(3): 166-179. https://doi.org/10.15345/iojes.2016.03.014

Tynjälä, P., Virtanen, A., Klemola, U., Kostiainen, E. and Rasku-Puttonen, H. 2016. Developing social competence and other generic skills in teacher education: Applying the model of integrative pedagogy. European Journal of Teacher Education 39(3): 368-387. https://doi.org/10.1080/02619768.2016.1171314 